\title{
Production of Garbage Enzyme from Different Fruit and Vegetable Wastes and Evaluation of Its Enzymatic and Antimicrobial Efficacy
}

\author{
Karuna Neupane ${ }^{1}$, Rama Khadka ${ }^{1}$ \\ ${ }^{1}$ Padma Kanya Multiple College, Bagbazar, Kathmandu, Nepal
}

*Corresponding author: Rama Khadka, Lecturer, Padma Kanya Multiple College, Bagbazar, Kathmandu, Nepal; Email: khadkarama2072@yahoo.com

\section{ABSTRACT}

Objectives: To evaluate the enzymatic and antimicrobial efficacy of enzyme from garbage produced from different fruits and vegetable wastes.

Methods: This study was conducted from October-2018 to February-2019 in the laboratory of Padma Kanya Multiple College, Bagbazar, Kathmandu, Nepal. This study was carried for production, analysis of enzymatic and antimicrobial efficacy by using yeast (Saccharomyces cerevisae) and bacteria (Bacillus species) in 5 fruits peels, Mosambi (Citrus limetta), Pomegranate (Punica granatum), Pineapple (Ananas comosus), Papaya (Carica papaya) and mixed fruits collected from fresh fruit stall and vegetable peels collected from college's hostel. The fermentation mixture was made in the ratio 1:3:10 (1 part brown sugar, 3 parts fruits/vegetable peels and 10 parts water) and left for 3 months for fermentation.

Results: After fermentation, enzyme activity (amylase, protease, caseinase, cellulase and lipase) and antimicrobial efficacy (S. aureus, S. aureus (ATCC 25923), Bacillus spp, Salmonella Typhi, E. coli, E. coli (ATCC 25922), Shigella spp, Pseudomonas aeruginosa) were analyzed. All the samples showed amylase and caseinase enzyme activity, only Pineapple (Ananascomosus), Papaya (Carica papaya) and Mixed fruit showed protease enzyme activity while only Pomegranate (Punicagranatum) showed lipase enzyme activity. In antimicrobial efficacy test, garbage enzyme produced from vegetable sample didn't show antimicrobial activity with bacteria used except E. coli (ATCC 25922)and S. aureus (ATCC 25923). Similarly, garbage enzyme produced from Mixed fruit and Papaya (Carica papaya) didn't show antimicrobial activity with Salmonella Typhi and S. aureus (ATCC 25923) respectively but garbage enzyme from other wastes showed antimicrobial activity with bacteria used in test.

Conclusion: Different fruits and vegetables wastes showed different enzyme activity and antimicrobial activity.

Key words: Garbage enzyme, fruits, vegetables, Antimicrobial susceptibility test.

\section{INTRODUCTION}

Garbage enzymes are the organic solution produced by the simple fermentation of fresh vegetable wastes, fruit wastes with addition of brown sugar and water by using the selective microorganisms like Yeast and Bacteria (Thirumurugan 2016). This fermentation creates a vinegar like liquid with natural proteins, mineral salts and enzymes that make it magnificently multipurpose in and out of the home. In 2006, a researcher from Thailand named Rosukun developed a solution from product using organic solid waste

Date of Submission: October 3, 2019

Published Online: December, 2019 and named it garbage enzyme (Chelliah and Palani 2015). This enzyme is composite organic substance made up of organic acids, proteins chains (enzyme), and minerals salts produced by fermentation of waste vegetables, fruits, or its peels, sugars, and water. The garbage enzyme can be applied to compose, decompose, transform, and catalyze (Palanisamy and Palani 2017). The functions of garbage enzyme are to resolve (decompose), transform (change), and catalyze the reduction (Voet 2012).

Fruits and vegetable wastes are produced in large

Date of Acceptance: December 4, 2019

DOI: https:/ / doi.org/10.3126/tujm.v6i0.26594 
quantities in market and constitutes a source of nuisance in municipal landfills because of their high biodegradability (Virtrurtia et al. 1989). Garbage/citrus enzymes is different from fruit enzymes and is not for human consumption. It is a nutritious drink prepared through proper fermentation of fruits. Garbage/citrus enzymes is used as a natural household cleaner; air purifier; deodorizer; insecticides; detergent; body care; organic fertilizer etc. It removes odor and dissolve toxic air released from smoking, car exhaust, chemical resides, from household products etc. Enzymes that flow underground will eventually purify the river and the sea. It reduces mosquitos, flies, rats, cockroaches etc. It is a natural antiseptic for your home. It prevents drain pipe blockages (Pinang 2012).

\section{MATERIALS AND METHODS}

\section{Sample size, sample site and duration of study}

The study was done from October 2018 to February 2019. A total 6 samples including 5 fruits peels sample i.e. Lime (Citrus aurantiifolia), Pineapple (Ananas comosus), Pomegranate (Punica granatum), Papaya (Carica papaya) and mixed fruit and one vegetable peels sample was taken for the study. Fruit peels were collected from various fresh juice stall near Padma Kanya Campus. Similarly, vegetables peels were collected from the hostel's kitchen of Padma Kanya Campus.

\section{Study design}

Purposive/judgement sampling was performed for sample selection and cross-sectionals-descriptive study designed was performed.

\section{Preparation of fermentation medium}

The collected fruits and vegetable samples were mixed in 1:3:10 (1part molasses, 3 parts fruits/ vegetables peels and 10 parts water) for the fermentation process. Air tight plastic jars were used for fermentation process. In this mixture, 3 tea spoonful of yeast powder (Saccharomyces cerevisiae) and $10 \mathrm{ml}$ of bacterial suspension (Bacillus species) was added. Then the jars were left for fermentation for 12 weeks (Thirumurugan 2016). After 12 weeks, enzyme activity test and antimicrobial efficacy test was performed. For the enzymatic and antimicrobial assay, the fermented mixtures were centrifuged at $5000 \mathrm{rpm}$ for 10 minutes. The supernatant (crude garbage enzyme) was used to analyzed enzyme activity and antimicrobial efficacy test (Sarkar et al. 2011).

\section{Screening of enzyme activity}

TUJM VOL. 6, NO. 1, 2019

\section{Amylase}

For amylase enzyme activity, agar-agar with $1 \%$ starch was prepared aseptically. With help of sterile cork borer, $4 \mathrm{~mm}$ size wells were made in which $50 \mu \mathrm{l}$ of enzyme from garbage was inoculated then the plates were incubated for 48 hours at $37^{\circ} \mathrm{C}$. Hydrolysis of starch was visualized as clear zones around the wells of plates against deep blue brown for starch by flooded with iodine solution (Emimol et al. 2012). Diameter of the clear zone was measured and the activity level of the microorganisms was determined by the diameter of the clear zone formed.

\section{Cellulase}

The cellulase agar was prepared with $1 \%$ carboxy methyl cellulose aseptically. With the help of sterile cork borer of $4 \mathrm{~mm}$ size, wells were made in plates in which $50 \mu$ l of enzyme from garbage was inoculated in well and plates were incubated at $37^{\circ} \mathrm{C}$ for 24 hours - 48 hours, the plates were flooded with $0.3 \%$ congored solution for 10 minutes. Then it was washed with water and flooded with $1 \mathrm{~N} \mathrm{NaCl}$ as distaining solution. Cellulase production is visualized by translucent zone around the colonies. Diameter of the translucent zone was measured and the activity level of the microorganisms was determined by the diameter of the translucent zone formed (Thirumurugan 2016).

\section{Protease}

The protease agar was prepared with $1 \%$ gelatin aseptically. With help of sterile cork borer of $4 \mathrm{~mm}$ sizes, wells were made in plates in which $50 \mu 1$ of enzyme from garbage was inoculated then the plates were incubated at $37^{\circ} \mathrm{C}$ for 24 hours- 48 hours. After incubation plates were flooded with acidic mercuric chloride solution and were allowed to stand for 5-10 mins, excess solution was decanted. Appearance of a clear zone around the colonies demonstrated the positive result for the proteolytic hydrolysis of gelatin by the enzyme gelatinase. Diameter of the clear zone was measured and the activity level of the microorganisms was determined by the diameter of the clear zone formed. Unhydrolyzed and continuous opaque zone around the growth indicates the absence of gelatinase enzyme. Diameter of the clear zone was measured and the activity level of the microorganisms was determined by the diameter of the clear zone formed (Emimol 2012).

\section{Caseinase}

The casein hydrolysis test was done by inoculation 
of the garbage enzyme to be tested on the agar plates containing $1 \%$ skimmed milk powder. With help of sterile cork borer of $4 \mathrm{~mm}$ size wells, were made prepared in $50 \mu 1$ of enzyme from garbage was inoculated then the plates were then incubated at $37^{\circ} \mathrm{C}$ for 24 hours- 48 hours. After incubation plates were flooded with copper sulphate solution and excess solution was decanted off. Formation of a clear zone was observed around the well and the diameter of the clear zone was measured. Diameter of the clear zone was measured and the activity level of the microorganisms was determined by the diameter of the clear zone formed (Sazci et al. 1986)

\section{Lipase}

1\% Tween-20 hydrolysis agar medium was prepared. With help of sterile $4 \mathrm{~mm}$ cork borer, wells were made one plate was. The wells were labelled by the name of the sample to be inoculated.50 $\mu 1$ of each sample was added to well. The plates were at $37^{\circ} \mathrm{C}$ for 24 hours. After the incubation, the clear zone of hydrolysis was observed around well (Emimol 2012).

\section{Antimicrobial efficacy test}

The crude extract of garbage enzyme was screened for its antimicrobial activity i.e. determination of zone of inhibition against tested organisms by agar well diffusion method as given by Balouiri et al. (2016). According to CLSI 2012, 3- 4 fresh bacterial culture colonies was inoculated in nutrient broth and incubated for 4 hours then compared its turbidity standard 0.5 McFarland. Sterile cotton swab was dipped into the prepared inoculums, rotated and pressed against the upper inside wall of the tubes to express excess fluid. The entire agar plate was streaked 3 times, turning the plate at $60^{\circ}$ angle between each streaking. Inoculums was allowed to dry for 5-10 minutes. Then with the help $4 \mathrm{~mm}$ sterile cork borer, wells were made in the inoculated media plates then $50 \mu 1$ of the suspension of different garbage was inoculated into the well with the help of micropipette. The plates were then left for half an hour and incubated at $37^{\circ} \mathrm{C}$ overnight. After incubation, the plates were viewed for the zone of inhibition (clear zone) without the growth around the well. The zones of inhibition were measured using a scale and mean was recorded. For the quality control of antimicrobial activity, ATCC culture of S. aureus (ATCC 25923) and E. coli (ATCC 25922) were used.

\section{RESULTS}

Table 1: Enzymatic activity of crude garbage enzyme in particular agar medium

\begin{tabular}{lccccc}
\hline Name of the sample & \multicolumn{5}{c}{ Zone of inhibition $(\mathrm{mm})$ in different media } \\
\cline { 2 - 6 } & $\begin{array}{c}\text { Starch hydrolysis } \\
\text { agar }\end{array}$ & $\begin{array}{c}\text { Gelatin } \\
\text { hydrolysisagar }\end{array}$ & $\begin{array}{c}\text { Skimmed milk } \\
\text { agar }\end{array}$ & $\begin{array}{c}\text { Tween-20 } \\
\text { hydrolysis agar }\end{array}$ & $\begin{array}{c}\text { Cellulose } \\
\text { hydrolysis agar }\end{array}$ \\
\hline $\begin{array}{l}\text { Mosambi (Citrus } \\
\text { limetta) }\end{array}$ & 29 & 0 & 10 & 0 & 0 \\
$\begin{array}{l}\text { Pomegranate (Punica } \\
\text { granatum) }\end{array}$ & 35 & 13 & 18 & 28 & 0 \\
$\begin{array}{l}\text { Pineapple (Ananas } \\
\text { comosus) }\end{array}$ & 28 & 15 & 12 & 0 & 0 \\
$\begin{array}{l}\text { Papaya (Carica } \\
\text { papaya) }\end{array}$ & 21 & 10 & 10 & 0 & 0 \\
$\begin{array}{l}\text { Mixed Fruits } \\
\text { Vegetables }\end{array}$ & 23 & 8 & 12 & 0 & 0 \\
\hline
\end{tabular}

Table 2: Antimicrobial activity of crude garbage enzyme on Gram positive bacteria

\begin{tabular}{lccc}
\hline Name of the sample & \multicolumn{2}{c}{ Zone of inhibition (mm) on Gram positive bacteria } \\
\cline { 2 - 4 } & S. aureus & S. aureus (ATCC 25923) & 16 \\
\hline $\begin{array}{l}\text { Mosambi } \\
\text { (Citrus limetta) }\end{array}$ & 16 & 25 \\
$\begin{array}{l}\text { Pomegranate } \\
\text { (Punica granatum) }\end{array}$ & 30 & 24 \\
$\begin{array}{l}\text { Pineapple } \\
\text { (Ananas comosus) }\end{array}$ & 23 & 0 & 18 \\
$\begin{array}{l}\text { Papaya } \\
\text { (Carica papaya) }\end{array}$ & 18 & 14 & 22 \\
Mixed Fruits & 12 & 19 & 13 \\
Vegetables & 0 & 16 & 0 \\
\hline
\end{tabular}


Table 3: Antimicrobial activity of crude garbage enzyme on Gram negative bacteria.

\begin{tabular}{|c|c|c|c|c|c|}
\hline \multirow[b]{2}{*}{ Name of the sample } & \multicolumn{4}{|c|}{ Zone of inhibition $(\mathrm{mm})$ on Gram negative bacteria } & \multirow[b]{2}{*}{$\begin{array}{c}\text { E. coli (ATCC } \\
25922 \text { ) }\end{array}$} \\
\hline & Shigella spp & $\begin{array}{l}\text { Pseudomonas } \\
\text { aeruginosa }\end{array}$ & Salmonella Typhi & E. coli & \\
\hline Mosambi (Citrus limetta) & 20 & 17 & 20 & 18 & 24 \\
\hline $\begin{array}{l}\text { Pomegranate (Punica } \\
\text { granatum) }\end{array}$ & 19 & 13 & 18 & 24 & 21 \\
\hline Pineapple (Ananas comosus) & 28 & 25 & 20 & 18 & 27 \\
\hline Papaya (Carica papaya) & 17 & 21 & 15 & 14 & 14 \\
\hline Mixed Fruits & 20 & 18 & 0 & 17 & 19 \\
\hline Vegetables & 0 & 0 & 0 & 0 & 23 \\
\hline
\end{tabular}

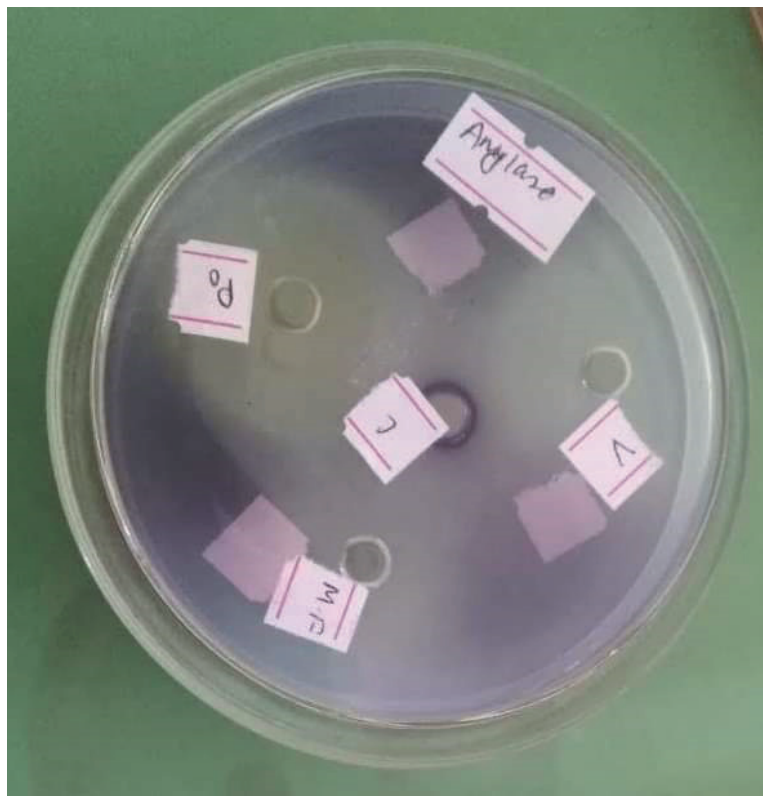

$\mathrm{V}=$ Vegetable

M.F= Mixed fruit

$\mathrm{Po}=$ Pomegranate

$\mathrm{C}=$ Control

Photograph 1: Amylase enzyme activity of crude garbage enzyme

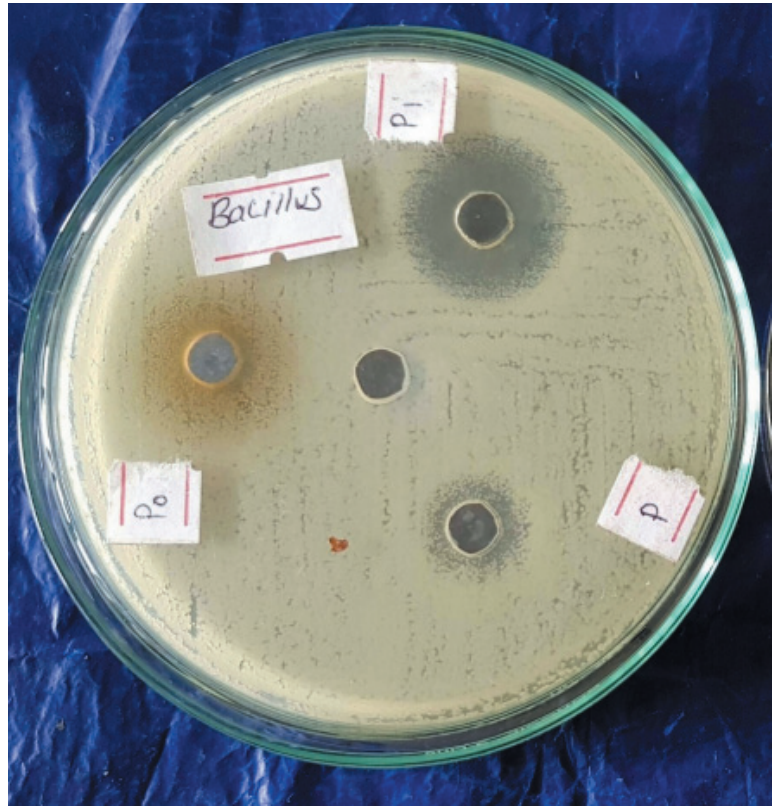

$\mathrm{Pi}=$ Pineapple

$\mathrm{P}=$ Papaya

$\mathrm{Po}=$ Pomegranate

Center $=$ control

Photograph 2: Antimicrobial efficacy test of crude garbage enzyme in Bacilus species 


\section{DISCUSSION}

In gelatin agar plate, only Pineapple(15mm), Papaya $(10 \mathrm{~mm})$ and Mixed fruit $(8 \mathrm{~mm})$ showed protease enzyme activity. Analysis of protease enzyme activity in gelatin agar plate by Thirumurugan (2016) taking Orange, Pomegranate, Mosambi and Watermelon as sample analyzed that in the pomegranate sample, the activity was slightly higher than other samples. In Thirumurugan study, pomegranate showed the zone of inhibition which was $34 \mathrm{~mm}$. However, Pomegranate didn't show the protease enzyme activity, reasons could be the difference in fermentation time of samples. In the study conducted by Madhumithah et al. (2011) using five vegetable wastes samples such as Potato, Brinjal, Pumpkin, Cauliflower and Cabbage, protease enzyme produced by solid state fermentation using Aspergillus niger showed maximum enzyme production in case of cauliflower substrate with an activity of $1.082 \mathrm{U}$ g- 1 and minimum production of $0.43 \mathrm{U}$ g- 1 of potato substrate. Protease enzyme was produced in both studies but the difference was based on whether the protease enzyme produced or not whereas total amount of protease produced in each sample per gram of substrate was calculated in the study of Madhumithah et al. (2011).

In starch hydrolysis agar, all the six samples showed the amylase enzyme activity. Pomegranate showed maximum amylase enzyme activity $(35 \mathrm{~mm})$ whereas Papaya showed the minimum amylase enzyme activity $(21 \mathrm{~mm})$. However, in the study conducted by Thirumurugan (2016) in case of amylase enzyme activity in caesine agar plate, Orange, Mosambi, Watermelon and Pomegranate were included as the sample, only Watermelon (15mm) and lime (19mm) showed the amylase activity. This difference is may due to the difference in the fermentation period and difference in the agar plate used.

In this study, all the six samples of fruits and vegetables waste showed casein hydrolysis. Among all the sample Pomegranate showed the maximum casein hydrolysis $(18 \mathrm{~mm})$ whereas vegetable sample showed the minimum casein hydrolysis $(9 \mathrm{~mm})$. This may conclude that all the sample produced caseinase enzyme during fermentation.

None of the fruits and vegetable sample showed cellulase enzyme activity which means that there was no production of cellulase during fermentation in all sample. But in the study conducted by Thirumurugan
(2016) taking Orange, Watermelon, Mosambi and Pomegranate as the sample, only Water melon (18mm) and Mosambi $(12 \mathrm{~mm})$ showed the cellulase enzyme activity however pomegranate didn't show the cellulase enzyme activity which means that Pomegranate may not produce cellulase enzyme. Mosambi did not show the cellulase enzyme activity which could be the difference factors like $\mathrm{pH}$ of the garbage enzyme, temperature etc. Duration of the fermentation of sample may also affected the cellulase enzyme activity. Among the six different fruits and vegetable samples, only Pomegranate showed lipase enzyme activity. This may also that only Pomegranate sample produced lipase enzyme activity during fermentation.

In this study the antimicrobial activity of enzyme from garbage on Gram positive and Gram-negative bacteria showed different zone of inhibition. Enzyme garbage produced from Papaya (Carica papaya) and mixed fruit showed no antimicrobial activity with S. aureus (ATCC 25923) and Salmonella Typhi respectively whereas garbage enzyme produced from vegetable wastes showed antimicrobial activity only with S. aureus (ATCC 25923) and E. coli (ATCC 25922). Garbage enzyme produced from other samples showed antimicrobial activity with the Gram positive and Gram-negative bacteria used in the test. However, in the study conducted by Saramanda and Kaparapu (2017), the antimicrobial activity of garbage enzyme from citrus fruit peels extract showed zone of inhibition higher. It was observed by using $150 \mu 1$ of garbage enzyme solution, the zone of inhibition for $E$. coli, S. aureus, Streptococcus pyogens, Salmonella Typhi and Pseudomonasa eruginosa were $11 \mathrm{~mm}, 10 \mathrm{~mm}, 10 \mathrm{~mm}$, $13 \mathrm{~mm}$ and $9 \mathrm{~mm}$ respectively. These difference in zone of inhibition might be due to the difference in the type of sample producing garbage enzymes. Also, the concentration of garbage enzyme diffused in well was different in both studies.

\section{CONCLUSION}

Different fruits and vegetables wastes showed different enzyme activity and antimicrobial activity. Enzymes produced from garbage showed the antimicrobial activity with Gram positive and Gram-negative bacteria so the garbage enzyme should be utilized to kill/inhibit the pathogens in house as well as laboratory.

\section{ACKNOWLEDGEMENTS}

We would like to express our gratitude to Department 
of Science, Padma Kanya Multiple Campus, Bagbazar for providing opportunity for doing this research work. We are also grateful and deeply indebted to Mr. Amrit Acharya, Department of Microbiology, Padma Kanya Multiple Campus for valuable suggestion.

\section{CONFLICT OF INTEREST}

The authors declare no conflict of interest.

\section{REFERENCES}

Balouiri M, Sadak M and Ibnsounda SK (2016). Methods for in vitro evaluating antimicrobial activity. $J$ Pharm Anal 6: 71-79.

Chelliah A and Palani S (2015). Investigation of biocatalytic potential of garbage enzymeand its influence on stabilization of industrial waste activated sludge. Process Safety and Environmental Protection 94: 471-478.

Emimol A, Ganga G, Parvathy R, Radhika G and Nair GM (2012). Screening of microbes producing extracellular hydrolytic enzyme from corporation waste dumping site and house hold waste for the enhancement of bioremediation methods. IOSRJPBS 4(1): 54-60.

Madhumithah CG, Krithiga R, Sundharam S, Changam SS, Guthakurta S and Cherian KM (2011). Utilization of vegetables wastes for production of protease by solid state fermentation by using Aspergillus niger. World J Agric Sci 7(5): 550-555.

Palanisamy S and Palani (2017). Optimization of lipase production from organic solid waste by anaerobic digestion and its application in biodiesel production. Fuel Process Technol 165: 1-8.
Pinang PS (2012). Change climate. http://www. enzymesos.com accessed on August 16, 2019.

Saramanda G and Kaparapu J (2017). Antimicrobial activity of fermented citrus fruit peel extract. Int Journal of Engineering Research and Application 7: 25-28.

Sarkar P, Meghvanshi M and Singh R (2011). Microbial consortinum: Approach in effective degradation of organic kitchen wastes. IJEST 2(3): 170-174.

Sazci A, Erenler K and Radford A (1986). Detection of cellulolytic fungi by using Congo red as an indicator: a comparative study with the dinitrosalicyclic acid reagent method. J Appl Bacteriol 61(6): 559-562.

Selvakumar P and Sivashanmugam P (2017). Optimization of lipase production from organic solid waste by anaerobic digestion and its application in biodiesel production. Fuel Process Technol 165: 1-8.

Thirumurugan P (2016). Production and analysis of enzyme bio-cleaners from fruit and vegetable wastes by using yeast and bacteria. Student project Report (D.O.Rc.No.1082/2015A; Project No: 28) submitted to Tamil Nadu State Council for Higher Education (TANSCHE), India pp: 4-6.

Viturtia A, Alvarez JM, Cecchi F and Fazzini G (1989). Two-phase anaerobic digestion of a mixture of fruit and vegetable waste. Biol Wastes 29: 189-99.

Voet V (2012). Ways to save energy (2012). http:// www.waystosaveenergy.net accessed on August 16, 2019. 